\title{
MODEL ALOKASI DANA PERIMBANGAN DAN PENDAPATAN ASLI DAERAH (PAD) UNTUK KEMASLAHATAN UMMAT
}

\begin{abstract}
Keterbukaan pengelolaan keuangan daerah yang telah terlaksana sejak era otonomi daerah menjadi dasar untuk mewujudkan pemerintahan yang good governance and clean governance, dan secara tidak langsung menjadikan sebuah kebebasan dan keleluasaan bagi pemerintah daerah untuk mampu menggali dan memanfaatkan segala sumber daya yang mereka miliki, besarnya dana transfer yang diberikan oleh pemerintah pusat dalam bentuk dana perimbangan harus bisa digunakan untuk sebesar - besar kesejahteraan rakyat dimana wujud berhasilnya sebuah pemerintahan daerah adalah kemerataan program pemerintahan.

Penelitian ini menggunakan data sekunder yang diambil dari laporan keuangan pemerintah daerah se Jawa Tengah dengan ukuran PAD dan Dana Perimbangan, dasar dari penggunakan indicator tersebut dikarenakan tingkat kesejahteraan masyarakat akan mungkin dicapai ketika pengelolaan dana tersebut bisa dirasakan langsung dan merata dikalangan masyarakat.

Hasil dari penelitian ini menyimpulkan bahwa keseluruhan penerimaan daerah memberikan pengaruh yang sangat siginifikan terhadap kemaslahatan ummat, hal ini ditunjukkan dengan besarnya nilai uji $F$ 86,711 dengan tingkat signifikansi 0,000 yang berarti $86,711 \%$ indikator kemaslahatan ummat dipengaruhi oleh varibel PAD, DAU, DAK dan DBH. Dari hasil ini bisa juga disimpulkan bahwa pemerintah secara tidak langsung berandil besar dalam mewujudkan kesejahteraan masyarakatnya.
\end{abstract}

\section{PENDAHULUAN}

Islam mengajarkan akan tanggung jawab dari pemimipin untuk meningkatkan kesejahteraan rakyat, landasan ini setidaknya harus diterapkan dalam pemenuhan pemerintahan yang good governance and clean government agar semua rakyat merasakan kesejahteraan, hal ini diutarakan dalam hadis ibnu umar r.a."saya telah mendengar rasulullah SAW bersabda : setiap orang adalah pemimpin dan akan diminta pertanggungjawaban atas kepemimpinannya. Seseorang kepala Negara akan diminta pertanggungjawaban perihal rakyat yang dipimpinnya. Seorang suami akan ditanya perihal keluarga yang dipimpinnya. Seorang istri yang memelihara rumah tangga suaminya akan ditanya perihal tanggungjawab dan tugasnya. Bahkan seorang pembantu/ pekerja rumah tangga yang bertugas memelihara barang milik majikannya juga akan ditanya dari hal yang dipimpinnya, dan kamu sekalian pemimpin dan akan ditanya (diminta pertanggungjawaban) dari hal yang dipimpinnya. (HR. Buchari dan Muslim).

Hadis diatas secara jelas menjelaskan betapa islam sangat berhati - hati dalam masalah kepemimpinan, kesejahteraan seseorang yang dipimpinnya menjadi sebuah kewajiban mutlak, oleh sebab itu pengelolaan anggaran yang meliputi berbagai dana yang telah dialokasikan dari pusat ke daerah harus benar - benar berimplikasi pada kepentingan rakyat, tidak mungkin pemimpin dikatakan berhasil apabila rakyat yang dipimpinnya masih dalam kondisi yang tidak sejahtera, Negara kita berpotensi menjadi makmur karena 
berlimpahnya sumber daya alam yang ada dan bisa dikelola, tetapi jika pemimpin tidak bisa mengatur ini semua maka kemakmuran dalam hal ini prinsip otonomi daerah tidak akan pernah terwujud.

Otonomi daerah mengenalkan asas tentang desentralisasi fiskal dimana setiap daerah diberikan hak secara penuh untuk menentukan segala kebijakan terkait anggaran yang telah mereka miliki yang salah satu sumber utamaya berasal dari pemerintah pusat. Dalam hal desentralisasi ini pemerintah daerah diwajibkan untuk menyusun rancangan anggaran setiap tahun dengan menekankan pada rancangan anggaran berbasis kinerja, hal ini dimaksudkan agar pemerintah daerah merencanakan program kerja secara mandiri dengan mengkalkulasi besarnya belanja yang akan dikeluarkan serta membandingkan besarnya pendapatan yang akan diperoleh daerah tersebut.

Pendapatan asli daerah (PAD) sampai saat ini disetiap daerah di Indonesia bisa dibilang masih sangat minim dari sektor sumber daya alam, umumnya pendapatan asli daerah yang diperoleh berasal dari sektor industri yang sedang dijalankan dimasing - masing daerah tersebut, padahal untuk sektor sumber daya alam di masing - masing daerah di Indonesia sangatlah besar jika pemanfaatan dan pengelolaannya diperhatikan oleh daerah tersebut. Daerah cenderung belum bisa melaksanakan otonomi daerah dari segi pengelolaan sumber - sumber daya alamnya, mereka sebagian besar cenderung mengandalkan pendanaan bagi pemerintah dari dana perimbangan.

Menurut Warsito, dkk (2008) mengatakan bahwa belanja daerah dirinci menurut urusan pemerintah daerah, organisasi, program, kegiatan, kelompok, jenis, objek dan rincian objek belanja. Belanja daerah dilakukan dalam rangka mewujudkan pendanaan pelaksanaan urusan pemerintah yang menjadi kewenangan Provinsi atau Kabupaten/Kota yang terdiri dari urusan wajib, urusan pilihan dan urusan yang penanganannya dalam bidang tertentu yang dapat dilaksanakan bersama - sama antara pemerintah pusat dan pemerintah daerah.

Menurut pakar ekonomi Islam al-Maqrizi (766-845 H), bahwa kecerobohan pemerintah (korupsi, administrasi birokrasi yang buruk) dalam mengelola anggaran dalam hal ini dana perimbangan sebagai sumber malapetaka dan krisis ekonomi. Maka selain kekayaan "diperlukan ketaqwaan dalam aktifitas dan kebijakan ekonomi," kata Yahya bin Umar (213-289 H). Ketakwaan merupakan asas ekonomi Islam. Itulah yang akan mendatangkan keberkahan dan kemakmuran (QS. Al-A'raf ayat 96).

Acuan dari penelitian ini merupakan pengembangan beberapa penelitian mengenai aspek yang hanya menitik beratkan pada Dana Alokasi Umum (Novita Puspita Sari (2009), sedangkan peneliti saat ini mencoba untuk memperluas variable yaitu tidak hanya dari DAU (Dana Alokasi Umum) saja, tetapi dari Dana Bagi Hasil, Dana Alokasi Khusus serta Pendapatan Asli Daerah, disamping itu peneliti saat ini juga menggunakan dasar keislaman yang bertujuan untuk memperkuat teori tidak hanya dari segi ilmu - ilmu sains tetapi juga ilmu agama. Objek utama dari penelitian ini adalah seluruh pemerintah kabupaten / kota yang ada di Jawa Tengah tahun 2012 - 2013. 


\section{Rumusan Masalah}

Uraian diatas menjelaskan secara umum permasalahan yang bisa terjadi karena adanya pengelolaan Pendapatan Asli Daerah dan Dana Perimbangan yang dimiliki oleh pemerintah daerah terhadap kemaslahatan ummat yang diukur dengan indikator Realisasi Belanja Daerah yang bisa dirumuskan sebagai berikut :

1. Apakah Alokasi Pendapatan Asli Daerah (PAD) berpengaruh terhadap tingkat kemaslahatan ummat di kabupaten / kota se Jawa Tengah tahun 2012 - 2013

2. Apakah Alokasi Dana Perimbangan berpengaruh terhadap tingkat kemaslahatan ummat di kabupaten / kota se Jawa Tengah tahun 2012 - 2013

\section{Tujuan Penelitian}

Penelitian yang akan dilakukan oleh peneliti ini bertujuan untuk:

1. Mengetahui dan menganalisis pengaruh dari alokasi Pendapatan Asli Daerah (PAD) terhadap tingkat kemaslahatan ummat di kabupaten / kota se Jawa Tengah tahun 2012 - 2013.

2. Mengetahui dan menganalisis pengaruh dari alokasi Dana Perimbangan terhadap tingkat kemaslahatan ummat di kabupaten / kota se Jawa Tengah tahun 2012 - 2013.

\section{Manfaat Penelitian}

Pemberian manfaat dari penelitian ini diharapkan bisa berkontribusi terhadap pihak - pihak berikut:

1. Bagi penulis dan akademisi

Mengembangkan kemampuan meneliti dan referensi dibidang akuntansi pemerintahan dan membandingkan antara teori dan praktek, serta menggunakan dasar-dasar keislaman untukmemperkuat dasar pengambilan kesimpulan terhadap objek yang diteliti.

2. Bagi pemerintah provinsi Jawa Tengah

Sebagai bahan masukan, perbaikan serta saran-saran nyata untuk mengevaluasi atas apa yang telah berjalan selama ini.

\section{TINJAUAN PUSTAKA}

\section{Landasan Teori}

\section{Kemaslahatan Ummat}

Hadis dari ibnu umar r.a. berkata : saya telah mendengar rasulullah SAW bersabda : setiap orang adalah pemimpin dan akan diminta pertanggungjawaban atas kepemimpinannnya. Seorang kepala negara akan diminta pertanggungjawaban perihal rakyat yang dipimpinnya. Seorang suami akan ditanya perihal keluarga yang dipimpinnya. Seorang isteri yang memelihara rumah tangga suaminya akan ditanya perihal tanggungjawab dan tugasnya. Bahkan seorang pembantu/pekerja rumah tangga yang bertugas memelihara barang milik majikannya juga akan ditanya dari hal yang dipimpinnya. Dan kamu sekalian pemimpin dan akan ditanya (diminta pertanggungan jawab) darihal hal yang dipimpinnya. (buchory, muslim). 
Pada dasarnya, hadis di atas berbicara tentang etika kepemimpinan dalam islam dimana kemaslahatan dan kesejahteraan masyarakat menjadi faktor utama. Dengan demikian, karena hakekat kepemimpinan adalah tanggung jawab dan wujud tanggung jawab adalah kesejahteraan, maka, presiden dalam memimpin negerinya bukan hanya sebatas menjadi pemimpin "pemerintah" saja, namun tidak ada upaya serius untuk mengangkat rakyatnya dari jurang kemiskinan menuju kesejahteraan, maka presiden tersebut belum bisa dikatakan telah bertanggung jawab. Karena tanggung jawab seorang presiden harus diwujudkan dalam bentuk kebijakan yang berpihak pada rakyat kecil dan kaum miskin, bukannya berpihak pada konglomerat dan teman-teman dekat. Oleh sebab itu, bila keadaan sebuah bangsa masih jauh dari standar kesejahteraan, maka tanggung jawab pemimpinnya masih perlu dipertanyakan.

Oleh sebab itu, mengingat kesetaraan poisi rakyat dan pemimpin ini, maka masing-masing memiliki hak dan tanggung jawabnya. Hadis di atas menjelaskan bahwa seorang pemimpin jangan hanya bisa memenuhi haknya, dan mengebiri hak rakyatnya, akan tetapi seorang pemimpin harus mengakui dan menjamin hak-hak rakyatnya secara bebas.

\section{Pendapatan Asli Daerah (PAD)}

Terwujudnya program pemerintah terkait dengan otonomi daerah adalah memberi kewenangan bagi daerah untuk mengeksplorasi segala sumber - sumber pendapatan atau penghasilan secara mandiri yaitu Pendapatan Asli Daerah (PAD). Menurut Halim (2001), Pendapatan Asli Daerah (PAD) adalah penerimaan daerah yang diperoleh dari sumber - sumber wilayahnya sendiri yang dipungut berdasarkan peraturan daerah sesuai dengan perundang - undangan yang berlaku. Adapun kelompok Pendapatan Asli Daerah (PAD) dipisahkan menjadi tiga jenis pendapatan yaitu :

1) Pajak daerah,

2) Retribusi daerah, Retribusi ini dirinci menjadi :

a) Retribusi jasa umum,

b) Retribusi jasa khusus,

c) Retribusi perijinan tertentu,

3) Hasil pengelolaan kekayaan yang dipisahkan

4) Lain - lain pendapatan asli daerah yang sah,

\section{Dana Perimbangan}

Berdasarkan UU No. 32 tahun 2004 dijelaskan bahwa pemerintah daerah merupakan satu kesatuan yang tidak bisa terpisahkan dari pemerintah pusat, maka dari itu pemerintah daerah tidaklah diwajibkan untuk mampu membiayai seluruh belanja daerah yang berasal dari Pendapatan Asli Daerah (PAD). Pemerintah pusat akan selalu memberikan bantuan kepada setiap daerah yang disalurkan melalui dana perimbangan.

Dana perimbangan yang bersumber dari Anggaran Pendapatan dan Belanja Negara (APBN) dapat dibagi menjadi 2 (dua) jenis yaitu dana transfer conditional grant (transfer bersyarat) yaitu Dana Alokasi Khusus (DAK), 
dan dana transfer unconditional grant (transfer tidak bersyarat) adalah Dana Alokasi Umum (DAU) dan Dana Bagi Hasil (DBH).

\section{Dana Alokasi Umum (DAU)}

Presentase proporsi Dana Alokasi Umum (DAU) antar provinsi dan Kabupaten / Kota dihitung berdasarkan perbandingan antara bobot urusan pemerintahan yang menjadi kewenangan provinsi kabupaten / kota. Dalam hal penentuan proporsi belum dapat dihitung secara kuantitatif, proporsi Dana Alokasi Umum (DAU) antar provinsi dan kabupaten / kota ditetapkan dengan imbangan 10\% untuk provinsi dan 90\% untuk kabupaten / kota.

Menurut Henley et al (2007) dalam Mardiasmo (2004:157), mengidentifikasi beberapa tujuan pemerintah pusat dalam memberikan dana bantuan berbentuk grant kepada pemerintah daerah, yaitu :

1) untuk mendorong terciptanya keadilan antar wilayah (geographical equity)

2) untuk meningkatkan akuntabilitas (promote accountability)

3) untuk meningkatkan system pajak yang lebih progresif, karena pada riilnya masyarakat yang berpenghasilan rendah terbebani tarif pajak yang tinggi.

4) Untuk meningkatkan keberterimaan (acceptability) pajak daerah, yaitu dengan memberikan subsidi beberapa pengeluaran daerah untuk mengurangi jumlah pajak daerah.

\section{Dana Alokasi Khusus (DAK)}

Termasuk bagian dari Dana Perimbangan, Dana Alokasi Khusus secara hakikat berasal dari APBN dan dialokasikan kepada daerah untuk membantu membiayai kebutuhan khusus. Dana Alokasi Khusus penyalurannya dilakukan dengan cara memindahbukukan dari rekening kas umum Negara ke rekening kas umum daerah, Dana Alokasi Umum tidak dapat digunakan untuk mendanai administrasi kegiatan, penyiapan kegiatan fisik, penelitian, pelatihan, dan perjalanan dinas. Kebutuhan khusus yang diurus oleh pemerintah daerah dan sesuai dengan prioritas nasional yaitu :

1) kebutuhan yang tidak dapat diperkirakan secara umum dengan rumus, kebutuhan yang bersifat khusus yang tidak sama dengan kebutuhan daerah lainnya, misalnya kebutuhan dikawasan transmigrasi, dan kebutuhan beberapa jenis investasi / prasarana baru, pembangunan jalan dikawasan terpencil, saluran irigasi primer dan saluran drainase primer.

2) Kebutuhan yang merupakan komitmen atau bersifat prioritas nasional, termasuk antara lain proyek yang dibiayai donor, pembiayaan reboisasi daerah dan proyek - proyek kemanusiaan untuk memenuhi kebutuhan dasar manusia.

\section{Dana Bagi Hasil (DBH)}

Menurut Elmi (2002:56) dana perimbangan pemerintah pusat dan daerah merupakan pembagian hasil penerimaan SDA dan penerimaan perpajakan. Yang termasuk pembagian hasil dari SDA yaitu minyak bumi, 
gas alam, pertambangan umum, kehutanan dan perikanan. sedangkan penerimaan dari sektor pajak yaitu pajak perseorangan (PPh), Pajak Bumi dan Bangunan (PBB), Bea Perolehan Hak atas Tanah dan Bangungan (BPHTB).

Pemberian dana bagi hasil oleh pemerintah pusat ini bertujuan untuk mengatasi masalah vertical fiscal balance yaitu menjamain keseimbangan antara kebutuhan fiskal dengan sumber - sumber fiskal pada berbagai tingkat pemerintah (Solihin, 2011). Fungsi dan kegunaan dana bagi hasil bisa dikatakan tidak berbeda dengan fungsi dana alokasi umum, dimana dana - dana ini bersifat "block grant" yang berarti apabila dana tersebut telah diterima oleh pemerintah daerah dalam kas daerah maka dana tersebut dapat dialokasikan pada berbagai belanja daerah sesuai dengan kebutuhan.

\section{Tingkat Belanja Pemerintah Daerah sebagai Indikator Kemaslahatan Ummat}

Pelaksanaan operasional dari pemerintah daerah untuk mewujudkan pembangunan secara merata maka dibutuhkan penataan system pengeluaran dan pembelanjaan yang tepat guna. Menurut Halim (2007:322) menyatakan bahwa belanja daerah adalah kewajiban pemerintah mengurangi nilai kekayaan bersih. Lebih lanjut Yuwono dkk, (2005:108) menyatakan bahwa belanja daerah adalah semua pengeluaran kas daerah atau kewajiban yang diakui sebagai pengurang nilai kekayaan bersih dalam periode satu tahun anggaran yang tidak akan diperoleh pembayarannya kembali oleh pemerintah.

Kemudahan dalam menentukan penempatan biaya atau belanja yang tepat sesuai program dan kegaitan dari pemerintah daerah maka diperlukan pengklasifikasian, berikut menurut Darise, 2008 belanja dibagi menjadi dua kategori :

a) Belanja tidak langsung, merupakan belanja yang penganggarannya tidak dipengaruhi secara langsung oleh adanya usulan program atau kegiatan. Kelompok belanja tidak langsung dibagi menurut jenis belanja terdiri dari : belanja pegawai, Belanja bunga Belanja Subsidi, Belanja Hibah, Belanja Bantuan Sosial, Belanja Bagi Hasil, Belanja Bantuan Keuangan, Belanja Tidak Terduga,

b) Belanja Langsung, merupakan belanja yang penganggarannya dipengaruhi secara langsung oleh adanya program atau kegiatan. Belanja langsung dibagi menurut jenis belanja yang terdiri dari : Belanja Pegawai, Belanja Barang dan Jasa, Belanja Modal,

\section{Penelitian Terdahulu}

Sebagai suatu kelayakan dalam sebuah penelitian adalah dengan memberikan data pembanding yang bisa dijadikan acuan atau dasar sehingga bukti atau referensi ilmiah bisa disajikan dengan benar, berikut beberapa penelitian terdahulu yang diyakini peneliti mempunyai suatu kesamaan dan dasar yang sejalan mengenai keuangan pemerintah daerah baik dari segi pendapatan yang diterima maupun dari segi pembelanjaan yang telah dan akan dikeluarkan. 


\section{Pengembangan Hipotesis}

Berdasarkan masalah penelitian dan landasan teori, maka kerangka konseptual penelitian ini terlihat pada gambar 1 (lampiran).

\section{Pengaruh Alokasi Pendapatan Asli Daerah (PAD) terhadap Realisasi Belanja Pemerintah Daerah}

Penerapan kebijakan desentralisasi fiskal disetiap daerah di Indonesia memberikan tujuan utama untuk mewujudkan adanya kemandirian dari suatu daerah menata, mengatur dan mengurus segala kepentingan yang terkait dengan masyarakat didaerahnya masing - masing. Kemampuan mengatur segala system keuangan baik dari segi pendapatan yang berasal dari daerah sendiri dan merealisasikan segala belanja daerah kearah yang tepat dan berguna bagi masyarakat baik untuk kesejahteraan bersifat fisik daerah maupun kesejahteraan dari sektor pendidikan dan kesehatan yang saat ini dirasa masih sangat minim.

Menurut Aramana (2011), Dari hasil penelitian tersebut menunjukkan bahwa PAD, Dana Perimbangan, Lain-lain Pendapatan Daerah yang sah berpengaruh signifikan terhadap Belanja Daerah dan kinerja keuangan pemerintah daerah bukan merupakan variabel moderating yang memperkuat hubungan antara PAD, Dana Perimbangan, Dan Lain-lain Pendapatan Daerah yang sah terhadap Belanja Daerah. Berdasarkan kejadian kejadian empiris yang terjadi dan penelitian - penelitan sebelumnya, maka hipotesis yang bisa dinyatakan sebagai berikut :

\section{H1 : Pendapatan Asli Daerah (PAD) berpengaruh positif terhadap realisasi belanja daerah.}

\section{Pengaruh Dana Perimbangan terhadap Realisasi Belanja Pemerintah Daerah}

Dana Alokasi Umum (DAU) menurut UU No. 33 Tahun 2004 adalah dana yang bersumber dari pendapatan APBN yang dialokasikan dengan tujuan pemerataan kemampuan keuangan antar daerah untuk mendanai kebutuhan daerah dalam rangka pelaksanaan desentralisasi.

Menurut Sari dan Yahya (2009). Secara Parsial Dana Alokasi Umum memberikan pengaruh yang signifikan terhadap Belanja langsung sedangkan Pendapatan Asli Daerah menunjukkan pengaruh yang tidak signifikan tethadap Belanja Langsung. Dan secara simultan Dana Alokasi Umum dan Pendapatan Asli Daerah secara bersama-sama mempunyai pengaruh signifikan terhadap Belanja Langsung. I

Dana Alokasi Khusus (DAK) yang telah dialokasikan kepada daerah untuk digunakan membiayai kegiatan khusus, hal ini berpengaruh terhadap realisasi belanja daerah karena penggunaan dana ini sendiri untuk investasi pembangunan, pengadaan, peningkatan dan perbaikan sarana fisik, inilah yang perlu dikaji seberapa sesuai realisasi belanja daerah meningkatan kesejahteraan masyarakat dan pelaksanaan desentralisasi. Muis (2012), Hasil penelitian tersebut menunjukkan bahwa Dana alokasi khusus berpengaruh langsung terhadap pertumbuhan ekonomi dan berpengaruh terhadap pertumbuhan ekonomi melalui belanja modal,

Semakin tinggi penenerimaan Dana Bagi Hasil (DBH), maka keuangan daerah akan semakin tercukupi dalam pengalokasian anggarannya yang sepenuhnya diserahkan kepada pemerintah daerah untuk digunakan atau direalisasikan dalam belanja daerah baik anggaran belanja pegawai maupun belanja modal. Peningkatan 
Dana Bagi Hasil (DBH) ini harus selalu ditingkatkan agar presentase penerimaan juga semakin besar dan diharapkan bisa merealisasikan dalam bentuk belanja yang efektif dan berbasis outcame tidak hanya output saja. Dari pertimbangan hasil penelitian ini dan beberapa kejadian - kejadian yang terjadi di pemerintah daerah maka hipotesis yang bisa ditarik adalah sebagai berikut :

H2 : Dana Alokasi Umum berpengaruh positif terhadap realisasi belanja daerah.

H3 : Dana Alokasi Khusus berpengaruh positif terhadap realisasi belanja daerah

H4 : Dana Bagi Hasil berpengaruh positif terhadap realisasi belanja daerah

\section{METODE PENELITIAN}

\section{Populasi dan Teknik Pengambilan Sampel}

Populasi yang dipakai dalam penelitian ini adalah seluruh kabupaten / kota yang ada di Jawa Tengah yang telah mempublikasikan laporan realisasi anggaran. Sampel dalam penelitian ini diambil dengan menggunakan metode purposive sampling, yaitu metode pengambilan sampel dengan kriteria - kriteria tertentu (Nur Indriantoro dan Bambang Supomo, 2002). kriteria yang akan digunakan harus mencakup hal - hal berikut ini :

1) Data yang digunakan adalah data tahun 2012-2013 dikarenakan data ini merupakan data yang bisa diperoleh adaro laporan keuangan masing - masing daerah di kabupaten / kota di provinsi jawa tengah.

2) Data harus tersedia di Badan Pusat Stastitik ataupun data di Kementerian Keuangan Republik Indonesia.

\section{Variabel Penelitian dan Definis Operasional}

Berdasarkan beberapa uraian tentang variable independen dan variable dependen maka definisi operasionalnya dapat digambarkan dalam Tabel 2 (lampiran).

\section{Teknik Analisis}

\section{Analisis Deskriptif}

Teknik analisis yang digunakan dalam penelitian ini meliputi statistic deskriptif. Statistik deskriptif adalah statistik yang memberikan gambaran atau deskripsi suatu data yang dilihat dari rata - rata (mean), maksimum dan minimum (Ghozali, 2009).

\section{Uji Asumsi Klasik}

Ghozali (2009) menerangkan bahwa model regresi yang diperoleh dari metode Ordinary Least Square (OLS) merupakan model regrei yang menghasilkan estimator linear tidak bias yang terbaik (Best Linear Unbias Estimator! Blue).

\section{Uji Normalitas Data}

Untuk menghindari bias, maka data yang digunakan harus berdistribusi normal. Uji normalitas dilakukan untuk menguji apakah model regresi, baik variabel dependen maupun independen, keduanya mempunyai distribusi data yang normal atau tidak (Ghozali, 2009).

\section{Uji Multikolinieritas}


Menurut Erlina (2011) ada dua uji multikolinearitas yang sering digunakan yaitu dengan melihat nilai VIF, semakin tinggi VIF semakin besar dampak dari multikolinearitas. Jika nilai VIF lebih besar dari 10 maka terjadi multikolinearitas yang cukup berat diantara variabel independen. UJi multikolinearitas yang kedua yaitu dengan melihat koefisien korelasi sederhana antara variabel-variabel independen/penjelas, apabila $r$ tinggi nilai absolutnya maka ada dua variabel penjelas tertentu berkorelasi dan masalah multikolinearitas ada dalam persamaan tersebut.

\section{Uji Autokorelasi}

Autokorelasi adalah keadaan dimana terjadi korelasi dari residual untuk pengamatan satu dengan pengamatan yang lain yang disusun menurut runtun waktu. Model regresi yang baik mensyaratkan tidak adanya masalah autokorelasi (Dwi Priyatno, 2009).

\section{Uji Heteroskedastisitas}

Heteroskesidasitas terjadi apabila variabel gangguan tidak mempunyai varians yang sama untuk semua observasi. Model regresi yang baik adalah homoskedesitas. Cara untuk mendeteksi ada tidaknya heteroskedasitas adalah dengan melihat grafik plot antara nilai prediksi variabel (ZPRED) dengan residualnya (SRESID). Jika ada pola tertentu, seperti titik - titik yang ada membentuk pola tertentu yang teratur bergelombang, melebar kemudian menyempit maka mengidentifikasikan telah terjadi heteroskedastisitas. Jika tidak ada pola yang jelas, serta titik - titik menyebar diatas dan dibawah angka nol pada sumbu Y maka tidak terjadi heteroskedastisitas.

\section{Metode Regresi Linear Berganda}

Inti dari metode Ordinary Least Squares adalah mengestimasi suatu garis regresi dengan jalan meminimalkan jumlah kuadrat kesalahan setiap observasi terhadap garis tersebut (Ghozali, 2009). Adapun persamaan umum yang digunakan dalam analisis regresi berganda adalah sebagai berikut :

$$
\mathrm{RBD}_{\mathrm{it}}=\beta_{0}+\beta_{1} \mathrm{PAD}+\beta_{2} \mathrm{DAU}+\beta_{3} \mathrm{DAK}+\beta_{4} \mathrm{DBH}
$$

Keterangan :

RBD : Realisasi Belanja Daerah

PAD : : Pendapatan Asli Daerah

DAU : Dana Alokasi Umum

DAK : Dana Alokasi Khusus

DBH : Dana Bagi Hasil

$\beta_{0}, \beta_{1}, \beta_{2}, \beta_{3}, \beta_{4} \quad$ : Koefisien penjelas masing-masing input nilai parameter $Y$.

\section{Uji Hipotesis}

\section{Koefisien Determinasi Berganda (R2)}

Koefisien determinasi berganda pada dasarnya mengukur seberapa jauh kemampuan model dalam menerangkan variasi variabel dependen (Gujarati, 2006). Hal tersebut digunakan untuk mengetahui kontribusi pengaruh indikator-indikator PAD, DAU, DAK dan DBH terhadap Realisasi Belanja Daerah. Uji koefisien 
determinasi (R2), untuk melihat berapa proporsi variasi dari variabel bebas secara bersama-sama dalam mempengaruhi variabel tidak bebas dengan melihat nilai adjusted $\mathrm{R}$ Square.

\section{Uji F}

Uji ini merupakan pengujian terhadap signifikansi model secara simultan atau bersama-sama, yaitu melihat pengaruh dari seluruh variabel bebas terhadap variable terikat. Untuk menentukan nilai $\mathrm{F}$ hitung tingkat signifikan yang digunakan sebesar $5 \%$ dengan derajat kebebasan $(\mathrm{df})=(\mathrm{k}-1)$ dan $(\mathrm{n}-\mathrm{k})$ kriteria sebagai berikut:

Jika F hitung $>$ F tabel maka Ho ditolak.

Jika F hitung $<$ F tabel maka Ho diterima

Uji t

Uji t digunakan untuk menguji koefisien regresi secara parsial dari variabel bebas terhadap variabel terikat.Untuk menentukan $\mathrm{t}$ tabel, taraf signifikan yang digunakan sebesar $5 \%$ dengan derajat kebebasan (df) $=(n-k-1)$, dimana $n$ merupakan jumlah observasi dan $\mathrm{k}$ merupakan jumlah variabel bebas. Pengujian hipotesis dilakukan dengan :

Jika t hitung $>$ t tabel maka Ho ditolak.

Jika t hitung $<\mathrm{t}$ tabel maka Ho diterima.

\section{HASIL DAN PEMBAHASAN}

Peneliti memperoleh sampel sebanyak 27 kabupaten dan kota di Jawa Tengah. Rincian dari sampel yang diperoleh peneliti terdapat pada Tabel 3 (lampiran).

Dari tabel 4.1 dijelaskan bahwa dari total keseluruhan kabupaten dan kota yang ada di Jawa Tengah yang telah menerbitkan laporan keuangan berturut - turut dari tahun 2012 sampai 2013 ada sebanyak 27 Kabupaten dan Kota, dan yang tidak menerbitkan secara berturut - turut sebanyak 7 Kabupaten dan Kota yaitu (Kab. Banjarnegara, Kab. Cilacap, Kab. Jepara, Kab. Pekalongan, Kab. Sukoharjo, Kab. Temanggung dan Kota Magelang).

\section{Analisis Data}

\section{Analisis Statistik Deskriptif}

Statistic deskriptif bertujuan untuk membandingkan nilai dari masing - masing sampel, baik nilai maksimum, minimum serta nilai rata - rata. Pada tabel 4.2 berikut ini merupakan hasil statistic deskriptif dari variabel Pendapatan Asli Daerah (PAD), Dana Alokasi Umum (DAU), Dana Alokasi Khusus (DAK), Dana Bagi Hasil (DBH) serta Realisasi Belanja Daerah.

\section{Uji Asumsi Klasik}

\section{Uji Normalitas}

Dari olah data dapat disimpulkan bahwa model regresi penelitian ini bisa digunakan karena telah 
memenuhi asumsi normalitas.

Disamping melihat grafik tersebut, pengujian normalitas data bisa juga dengan menggunakan uji statistic non-parametrik kolmogrov smirnov dengan alpha sebesar 5\%. Dari tabel 4.3 maka disimpulkan bahwa hipotesis nol tidak dapat ditolak atau dengan kata lain data telah terdistribusi secara normal.

\section{Uji Multikolinearitas}

Pada penelitian ini bisa ditemukan hasil seluruh variabel bebas dari multikolinearitas karena masing masing angka VIF dibawah 10 dan nilai tolerance lebih dari 0,10. Hasil penelitian ada pada tabel 4.4. dibawah ini.

\section{Uji Autokorelasi}

Ghozali (2008) dalam bukunya menjelaskan bahwa uji autokorelasi dalam penelitian ini digunakan untuk mengidentifkasi apakah terdapat autokorelasi antara error yang terjadi antar periode yang diujikan dalam model regresi, ada atau tidaknya autokorelasi bisa dilihat dari hasil uji D-W (durbin-watson).

\section{Uji Heteroskedastisitas}

Pengujian ini melihat tidak terjadinya heteroskedastisitas dengan didasarkan pada grafik scatterplot yang terlihat titik menyebar secara acak dan tidak membentuk pola tertentu yang jelas dan teratur dan juga titik tersebur menyebar dibawah anga 0 pada sumbu Y. grafik scaterplot dapat dilihat pada gambar 4.2 dibawah ini;

\section{Analisis Regresi Linear Berganda}

\section{Koefisien Determinasi}

Tabel 4.6 berikut merupakan hasil regresi dimana nilai adjusted R2 sebesar 0,866 yang bisa diartikan bahwa 86,6\% variasi realisasi belanja dapat dijelaskan dengan variabel independen PAD, DAU, DAK, dan DBH. Sedangkan sisanya 13,4\% dijelaskan dengan indikator atau variabel lain diluar model.

\section{Uji Signifikansi Simultan (Uji Statistik F)}

Bisa disimpulkan bahwa secara simultan seluruh variabel independen dalam penelitian ini berpengaruh secara signifikan terhadap realisasi belanja dikarenakan probabilitasnya lebih kecil dari 0,05.

\section{Uji t}

Hasil pengujian ini menunjukkan bahwa ketiga variabel memiliki nilai signifikansi dibawah 0,05 yaitu PAD, DAU dan DAK sedangkan untuk variabel DBH menunjukkan hasil yang tidak signifikan. Hasil estimasi model dalam persamaan dibawah ini :

$$
\text { Realisasi Belanja =0,497 PAD + 0,561DAU + 0, 191DAK + 0,048DBH }
$$




\section{Pembahasan Hipotesis}

\section{Pengaruh Alokasi Pendapatan Asli Daerah (PAD) terhadap Realisasi Belanja sebagai Indikator}

\section{Kemaslahatan Ummat}

Hipotesis pertama dalam penelitian ini menunjukan hasil bahwa Pendapatan Asli Daerah (PAD) berpengaruh terhadap Realisasi Belanja dengan hasil pengujian statistic sebesar 0,000 lebih kecil dari 0,05 sehingga variabel Pendapatan Asli Daerah ini bisa dikatakan berpengaruh secara signifikan terhadap Realisasi Belanja. Hasil ini sejalan dengan penelitian Aramana (2011) yang menyatakan bahwa Pendapatan Asli Daerah berpengaruh secara signifikan terhadap belanja daerah sedangkan kinerja keuangan pemda bukan merupakan variabel moderating yang memperkuat hubungan antara PAD terhadap belanja daerah.

Bati (2009) dalam penelitiannya juga menunjukkan adanya pengaruh secara parsial dari PAD terhadap pertumbuhan ekonomi. Disamping beberapa penelitian terdahulu yang menunjukkan hasil siginifikan ada pula hadis dari Abu Maryam Al'azdi yang mengatakan bahwa saya telah mendengar rasulullah SAW bersabda; siapa yang diserahi oleh Allah mengatur kepentingan kaum muslimin, yang kemudian ia sembunyi dari hajat kepentingan mereka, maka Allah akan menolak hajat kepentingan dan kebutuhannya pada hari qiyamat.

Apabila dilihat dari hasil penelitian ini dan beberapa penelitian - penelitian terdahulu dan juga dasar - dasar hadis dan ayat - ayat alqur'an tersebut bisa disimpulkan bahwa Alokasi PAD yang telah diberikan pemerintah mempunyai pengaruh yang signifikan terhadap Realisasi Belanja Daerah, sesuai dengan tujuan penelitian ini yang mengangkat kemaslahatan ummat maka bisa disimpulkan bahwa semakin besar alokasi PAD maka kemungkinan untuk peningkatan fasilitas public atau pelayanan masyarakat juga semakin tercapai, alokasi belanja yang sesuai kebutuhan masyarakat dan yang bisa dimanfaatkan di semua lini, tidak hanya berdasar pada input dan output tetapi seberapa besar outcome nya. Ukuran prosentase yang semakin tinggi dari outcome inilah yang bisa dijadikan dasar bagi meningkatnya kesejahteraan ummat.

\section{H1: Pendapatan Asli Daerah berpengaruh terhadap kemaslahatan umat}

\section{Pengaruh Alokasi Dana Alokasi Umum (DAU) terhadap Realisasi Belanja sebagai Indikator}

\section{Kemaslahatan Ummat}

Penelitian ini membuktikan bahwa Alokasi Dana Alokasi Umum (DAU) berpengaruh terhadap Realisasi Belanja pemerintah daerah dibuktikan dengan hasil pengujian statistic dengan angka 0,000 jauh dibawah 0,05 , selain itu penelitian terdahulu juga membuktikan hasil yang serupa seperti penelitiannya Noni Puspita dkk (2009) yang menyatakan bahwa secara parsial DAU berpengaruh signifikan terhadap belanja langsung, dan didukung juga oleh penelitiannya Muis (2012) yang menyatakan bahwa DAU berpengaruh langsung terhadap pertumbuhan ekonomi.

Pengalokasian belanja dari Dana Alokasi Umum yang telah ditentukan oleh pemerintah dirasa sudah sesuai dengan program yang direncanakan oleh pemerintah dengan bukti - bukti dari penelitian ini dan penelitian yang lain, kemaslahatan ummat yang diinginkan sudah terbangun dengan makin meningkatnya pembangunan yang didanai dari alokasi Dana Alokasi Umum. 


\section{H1: Dana Alokasi Umum berpengaruh terhadap kemaslahatan umat}

\section{Pengaruh Alokasi Dana Alokasi Khusus (DAK) terhadap Realisasi Belanja sebagai Indikator Kemaslahatan Ummat}

Dana Alokasi Khusus merupakan dana yang penggunaannya agak sedikit berbeda dari PAD, DAU dan DBH dimana DAK ini digunakan untuk kegiatan penghijauan dan reboisasi, dalam penelitian ini menunjukkan hasil yang signifikan ditunjukkan dengan angka 0,007 lebih kecil dari 0,05 disini sesuai dengan penelitian terdahulu yaitu menurut Muis (2012) yang menyatakan bahwa DAK berpengaruh terhadap pertumbuhan ekonomi melalui belanja modal. Bisa disimpulkan bahwa pemerintah dalam mengalokasikan Dana Alokasi Khusus ini sudah sesuai dengan prioritas nasional yang telah diatur oleh pemerintah bahwa kebutuhan masyarakat dikawasan khusus telah dilakukan dengan baik, terarah dan merata keseluruh daerah.

\section{H1: Dana Alokasi Khusus berpengaruh terhadap kemaslahatan umat}

\section{Pengaruh Alokasi Dana Bagi Hasil (DBH) terhadap Realisasi Belanja sebagai Indikator Kemaslahatan Ummat}

Hipotesis terakhir dalam penelitian ini menunjukkan pengaruh yang berbeda dengan ketiga hipotesis yang lain dimana dalam penelitian ini menghasilkan pengaruh negative antara alokasi Dana Bagi Hasil terhadap realisasi belanja yaitu ditunjukkan dengan nilai signifikansi 0,533 jauh lebih besar dari 0,05. Kesimpulan dari temuan ini bisa disebabkan oleh jenis pembelanjaan dari Dana Bagi Hasil ini sendiri yang berbeda dengan sumber dana yang lain, dimana DBH jenis pembelanjaannya bisa dilakukan secara bebas oleh daerah tersebut dengan mempertimbangkan kebutuhan akan daerah itu sendiri. Jika data menunjukkan hasil negative maka kemungkinan besar adalah indikator pemerintah daerah dalam membelanjakan DBH ini belum sesuai dengan potensinya dimana DBH ini dikhususkan untuk mengembangkan potensi - potensi sesuai daerah masing masing dan hubungan negative ini dimungkinkan pembelanjaannya belum sesuai dengan indikator tersebut.

\section{H1: Dana Bagi Hasil tidak berpengaruh terhadap kemaslahatan umat}

\section{PENUTUP}

\section{Kesimpulan}

1. Berdasarkan uji $\mathrm{F}$ bisa disimpulkan bahwa secara bersama - sama atau keseluruhan penerimaan daerah memberikan pengaruh yang sangat siginifikan terhadap kemaslahatan ummat, hal ini ditunjukkan dengan besarnya nilai uji F 86,711 dengan tingkat signifikansi 0,000 yang berarti 86,711\% indikator kemaslahatan ummat dipengaruhi oleh varibel PAD, DAU, DAK dan DBH.

2. Berdasarkan uji t, bisa ditarik beberapa kesimpulan yang berbeda dari setiap variabelnya dimana untuk variable PAD dan DAU berpengaruh terhadap kemaslahatan ummat dengan nilai signifikansi 0,000 lebih kecil dari 0,05, DAK juga berpengaruh terhadap kemaslahatan ummat dengan nilai signifikansi 0,007 
lebih kecil dari 0,05, sedangkan DBH tidak berpengaruh terhadap kemaslahatan ummat dengan nilai signifikansi 0,533 lebih besar dari 0,05.

\section{Keterbatasan Penelitian dan Saran}

1. Penelitian ini hanya sebatas meneliti kabupaten dan kota yang ada di Jawa Tengah sehingga tidak bisa mewakili keseluruhan kabupaten dan kota di Indonesia.

2. Sampel yang digunakan hanya merupakan data sekunder selama 2 (dua) tahun berturut - turut sehingga dirasa kurang bisa mewakili populasi secara keseluruhan.

3. Sumber data yang diolah hanya berupa data sekunder tidak didukung oleh data primer baik dari wawancara, unsure kebijakan daerah dan peraturan daerah lainnya yang berkaitan dengan kemaslahatan ummat.

4. Variable yang digunakan untuk mengukur indikator kemaslahatan ummat hanya dari factor penerimaan daerah tidak didukung oleh factor lain seperti pembiayaan daerah ataupun kerjasama antar daerah.

\section{Saran}

Atas dasar dari beberapa keterbatasan penelitian diatas, maka sebaiknya peneliti kedepan bisa memperlebar lagi cakupan penelitiannya dan indikator - indikator yang digunakan diharapkan lebih bervariasi bisa berupa data keuangan yang lebih banyak maupun data non keuangan sebagai pendukungnya.

\section{DAFTAR PUSTAKA}

Andirfa, Mulia. 2009. Pengaruh Pertumbuhan Ekonomi, Pendapatan Asli Daerah, Dana Perimbangan, Dan Lain-lain Pendapatan Yang Sah Terhadap Pengalokasian Anggaran Belanja Modal (Studi Empiris Pada Kabupaten/ Kota Pemerintah Aceh). Jurnal Akuntansi. Universitas Syiah Kuala Darussalam Banda Aceh.

Bati, 2009. Pengaruh Belanja Modal dan Pendapatan Asli Daerah (PAD) terhadap Pertumbuhan Ekonomi , (Studi Pada Kabupaten dan Kota di Sumatera Utara). Tesis Program Pascasarjana USU, Medan.

Darise, Nurlan.2008, Akuntansi Keuangan Daerah. Jakarta : PT.Indeks.

Elmi, Bacrul. 2002. Keuangan Pemerintah Daerah Otonom di Indonesia. UI-Press. Jakarta

Erlina. 2011. Metodologi Penelitian. USU Press. Medan

Ghozali, Imam. 2009. Aplikasi Analisis Multivariate dengan Program SPSS.Badan Penerbit Universitas

Diponegoro, Semarang.

Gujarati, Damodar, 2006. Ekonometrika Dasar, Penerbit Erlangga, Jakarta

Halim, Abdul. 2007. Pengelolaan Keuangan Daerah, Seri Bunga Rampai Manajemen Keuangan Daerah. UPP STIM YKPN. Yogyakarta.

Halim, Abdul. 2007. Akuntansi Keuangan Daerah. Salemba Empat. Jakarta.

Maimunah, Mutiara. 2006. "Flypaper Effect pada Dana Alokasi Umum (DAU) dan Pendapatan Asli Daerah

(PAD) Terhadap Belanja Daerah Studi Kasus Kabupaten/Kota di Pulau Sumatera“. Simposium Nasional 
Akuntansi XI. Padang.

Mardiasmo, 2002. Otonomi dan Manajemen Keuangan Daerah, Penerbit Andi. Yogyakarta.

Mardiasmo. 2002. Akuntansi Sektor Publik. Andi, Yogyakarta.

Mardiasmo, 2002. "Otonomi Daerah Sebagai Upaya Memperkokoh Basis Perekonomian Daerah". Makalah. Seminar Pendalaman Ekonomi Rakyat.

Muis, Noni Hilwa. 2012. Pengaruh Dana Alokasi Umum dan Dana Alokasi Khusus terhadap

Pertumbuhan Ekonomi dan Belanja Modal sebagai Variabel Intervening pada Kab/Kota di Provinsi Sumatera Utara.Tesis. Medan.

Peraturan Pemerintah No.104/2000 Tanggal 10 November 2000 Tentang Dana Perimbangan.

Peraturan Pemerintah Nomor 105 tahun 2000 tentang Pengelolaan dan Pertanggungjawaban Keuangan Daerah.

Peraturan Pemerintah No. 107 Tahun 2000 tentang "Pinjaman Daerah"

Peraturan Menteri Dalam Negeri No.13 Tahun 2006 Tentang Pedoman Pengelolaan Keuangan Daerah, Jakarta. Peraturan Menteri Dalam Negeri No.59 Tahun 2007 Tentang Pedoman Pengelolaan Keuangan Daerah. "

Priyatno, Dwi. 2008. Mandiri Belajar SPSS. MediaKom.Yogyakarta

Sari, Noni Puspita dan Idhar Yahya. 2009. Pengaruh Dana Alokasi Umum (DAU) dan Pendapatan Asli Daerah terhadap Belanja Langsung pada Pemerintah/Kota di Propinsi Riau. Jurnal Akuntansi 42. Fakultas Ekonomi Universitas Sumatera Utara.

Solihin, Dadang. 2011. Reformulasi Desentralisasi Fiskal dalam Instrumen DAU, DAK dan DBH. (http://www. slideshare.net/DadangSolihin/reformulasidesentralisasi-fiskal-dalam-instrumen-dau-dak-dan-dbh).

Undang-Undang No. 22 tahun 1999 tetang Pemerintah Daerah.

Undang-Undang 25 tahun 1999 tentang Perimbangan Keuangan antara Pemerintah Pusatdan Daerah. Undang-Undang no. 28 tahun 1999 Tentang Penyelenggaraan Negara Yang Bersih dan Bebas Dari KKN. Www. Djpk. Depkeu. go. id.

Yuwono, Sony. Dkk. 2005. Penganggaran Sektor Publik. Bayumedia Publising. Surabaya. 


\section{LAMPIRAN}

Tabel 1. Review Penelitian Terdahulu

\begin{tabular}{|c|c|c|c|}
\hline Peneliti & Judul Penelitian & $\begin{array}{l}\text { Variabel yang } \\
\text { digunakan }\end{array}$ & Hasil Penelitian \\
\hline $\begin{array}{l}\text { Noni } \\
\text { Puspita } \\
\text { Sari dan } \\
\text { Idhar Yahya } \\
\text { (2009) }\end{array}$ & $\begin{array}{l}\text { Pengaruh Dana } \\
\text { Alokasi Umum (DAU) } \\
\text { dan Pendapatan Asli } \\
\text { Daerah (PAD) terhadap } \\
\text { Belanja Langsung pada } \\
\text { Pemerintah / Kota di } \\
\text { Provinsi Riau }\end{array}$ & $\begin{array}{l}\text { Dana Alokasi } \\
\text { Umum (DAU), } \\
\text { PAD, dan Belanja } \\
\text { Langsung }\end{array}$ & $\begin{array}{l}\text { Secara parsial DAU memberikan pengaruh } \\
\text { yang signifikan terhadap belanja langsung } \\
\text { sedangkan PAD menunjukkan pengaruh yang } \\
\text { tidak signifikan terhadap belanja langsung. } \\
\text { Dan secara simultan DAU dan PAD secara } \\
\text { bersama - sama mempunyai pengaruh } \\
\text { signifikan terhadap belanja langsung }\end{array}$ \\
\hline $\begin{array}{l}\text { Aramana } \\
(2011)\end{array}$ & $\begin{array}{l}\text { Pengaruh PAD, Dana } \\
\text { Perimbangan dan lain-lain } \\
\text { pendapatan daerah yang } \\
\text { sah terhadap belanja } \\
\text { daerah dengan kinerja } \\
\text { keuangan pemda sebagai } \\
\text { variable moderating di } \\
\text { provinsi sumatera utara. }\end{array}$ & $\begin{array}{l}\text { PAD, Dana } \\
\text { Perimbangan, } \\
\text { lain - lain } \\
\text { pendapatan } \\
\text { daerah yang sah, } \\
\text { kinerja keuangan } \\
\text { dan belanja } \\
\text { daerah }\end{array}$ & $\begin{array}{l}\text { PAD, Dana perimbangan, lain - lain pendapatan } \\
\text { daerah yang sah berpengaruh signifikan } \\
\text { terhadap belanja daerah dan kinerja keuangan } \\
\text { pemda bukan merupakan variable moderating } \\
\text { yang memperkuat hubungan antara PAD, } \\
\text { dana perimbangan, dan lain - lain pendapatan } \\
\text { daerah yang sah terhadap belanja daerah. }\end{array}$ \\
\hline Muis (2012) & $\begin{array}{l}\text { Pengaruh DAU dan DAK } \\
\text { terhadap pertumbuhan } \\
\text { ekonomi dan belanja } \\
\text { modal sebagai variable } \\
\text { intervening pada } \\
\text { kabupaten/kota di } \\
\text { provinsi sumatera utara. }\end{array}$ & $\begin{array}{l}\text { DAU, DAK, } \\
\text { pertumbuhan } \\
\text { ekonomi dan } \\
\text { belanja modal }\end{array}$ & $\begin{array}{l}\text { DAU berpengaruh langsung terhadap } \\
\text { pertumbuhan ekonomi, DAK berpengaruh } \\
\text { langsung terhadap pertumbuhan ekonomi, } \\
\text { DAK berpengaruh terhadap pertumbuhan } \\
\text { ekonomi melalui belanja modal. DAK } \\
\text { berpengaruhlangsung terhadap pertumbuhan } \\
\text { ekonomi dan berpengaruh terhadap } \\
\text { pertumbuhan ekonomi melalui belanja modal. }\end{array}$ \\
\hline Bati (2009) & $\begin{array}{l}\text { Pengaruh belanja modal } \\
\text { dan PAD terhadap } \\
\text { pertumbuhan ekonomi }\end{array}$ & $\begin{array}{l}\text { Belanja } \\
\text { modal, PAD, } \\
\text { pertumbuhan } \\
\text { ekonomi }\end{array}$ & $\begin{array}{l}\text { 1. Secara simultan menunjukkan bahwa } \\
\text { belanja modal dan PAD berpengaruh } \\
\text { terhadap pertumbuhan ekonomi daerah di } \\
\text { kab/kota di Sumut. } \\
\text { 2. Secara parsial, PAD berpengaruh signifikan } \\
\text { terhadap pertumbuhan ekonomi, } \\
\text { sedangkan belanja modal tidak berpengaruh } \\
\text { terhadap pertumbuhan ekonomi di kab/ } \\
\text { kota di sumut. }\end{array}$ \\
\hline $\begin{array}{l}\text { Mulia } \\
\text { Andirfa } \\
\text { (2009) }\end{array}$ & $\begin{array}{l}\text { Pengaruh pertumbuhan } \\
\text { ekonomi, PAD, Dana } \\
\text { Perimbangan, dan lain- } \\
\text { lain pendapatan yang sah } \\
\text { terhadap pengalokasian } \\
\text { anggaran belanja modal } \\
\text { (studi empiris pada kab/ } \\
\text { kota pemerintah Aceh) }\end{array}$ & $\begin{array}{l}\text { DAU, PAD, dan } \\
\text { Belanja Langsung }\end{array}$ & $\begin{array}{l}\text { Secara parsial DAU memberikan pengaruh } \\
\text { yang signifikan terhadap belanja langsung } \\
\text { sedangkan PAD menunjukkan pengaruhh } \\
\text { yang tidak signifikan terhadap belanja } \\
\text { langsung. Dan secar simultan DAU dan PAD } \\
\text { secara bersama - sama mempunyai pengaruh } \\
\text { signifikan terhadap belanja langsung. }\end{array}$ \\
\hline
\end{tabular}


Tabel 2 Definisi Operasional Variabel

\begin{tabular}{|c|c|c|c|}
\hline $\begin{array}{c}\text { Jenis } \\
\text { Variabel }\end{array}$ & Definisi Operasional & Parameter & Skala \\
\hline $\begin{array}{l}\text { Pendapatan } \\
\text { Asli Daerah } \\
\text { (X1) }\end{array}$ & $\begin{array}{l}\text { Keseluruhan realisasi penerimaan daerah } \\
\text { dari pajak daerah, retribusi daerah, hasil } \\
\text { pengelolaan kekayaan daerah yang } \\
\text { dipisahkan dan lain - lain pendapatan asli } \\
\text { daerah yang sah }\end{array}$ & $\begin{array}{l}\text { Realisasi PAD } \\
2012-2013\end{array}$ & Rasio \\
\hline $\begin{array}{l}\text { Dana Alokasi } \\
\text { Umum } \\
\quad(X 2)\end{array}$ & $\begin{array}{l}\text { Keseluruhan transfer dana dari pemerintah } \\
\text { pusat kepada pemerintah daerah untuk } \\
\text { membiayai keseluruhan pengeluarannnya. }\end{array}$ & $\begin{array}{l}\text { Realisasi DAU } \\
2012-2013\end{array}$ & Rasio \\
\hline $\begin{array}{l}\text { Dana Alokasi } \\
\text { Khusus } \\
\quad \text { (X3) }\end{array}$ & $\begin{array}{l}\text { Dana yang berasal dari APBN yang } \\
\text { dialokasikan kepada daerah untukmembantu } \\
\text { membiayai kebutuhan khusus. }\end{array}$ & $\begin{array}{l}\text { Realisasi DAK } \\
2012-2013\end{array}$ & Rasio \\
\hline $\begin{array}{l}\text { Dana Bagi } \\
\text { Hasil } \\
\text { (X4) }\end{array}$ & $\begin{array}{l}\text { Keseluruhan transfer dana yang bersumber } \\
\text { dari hasil pajak dan bukan pajak. }\end{array}$ & $\begin{array}{l}\text { Realisasi DBH } \\
2012-2013\end{array}$ & Rasio \\
\hline $\begin{array}{l}\text { Realisasi } \\
\text { Belanja } \\
\text { Daerah } \\
\text { (Y) }\end{array}$ & $\begin{array}{l}\text { Jumlah anggaran pengeluaran daerah baik } \\
\text { yang langsung maupun tidak langsung } \\
\text { terkait dan berhubungan dengan progam } \\
\text { atau kegiatan. }\end{array}$ & $\begin{array}{l}\text { Realisasi Belanja Daerah } \\
\text { Tahun } 2012-2013\end{array}$ & Rasio \\
\hline
\end{tabular}

Tabel 3

Kriteria Sampel

\begin{tabular}{lc}
\hline \multicolumn{1}{c}{ Keterangan Sampel } & Jumlah Sampel \\
\hline Kabupaten dan Kota di Jawa Tengah & 34 Kabupaten dan Kota \\
$\begin{array}{l}\text { Data Laporan Keuangan tidak ada atau } \\
\text { kurang lengkap dari tahun } 2012-2013\end{array}$ & 7 Kabupaten dan Kota \\
$\begin{array}{l}\text { Kabupaten dan Kota yang dijadikan objek } \\
\text { penelitian }\end{array}$ & 27 Kabupaten dan Kota \\
\hline
\end{tabular}

Sumber : Data Sekunder 2016 yang telah diolah. 
Tabel 4

Statistik Deskriptif tahun 2012 - 2013

\begin{tabular}{lrrrrr}
\multicolumn{5}{c}{ Descriptive Statistics } \\
\hline PAD & $\mathrm{N}$ & Minimum & Maximum & \multicolumn{1}{l}{ Mean } & Std. Deviation \\
\hline DAU & 54 & 77798.9 & 925919.3 & $1.631 \mathrm{E} 5$ & 145451.1441 \\
DAK & 54 & 691.0 & $1.1 \mathrm{E} 6$ & $7.515 \mathrm{E} 5$ & 226275.1809 \\
DBH & 54 & 14993.0 & 118902.0 & $6.265 \mathrm{E} 4$ & 22734.7593 \\
BELANJA & 54 & 25300.2 & 156565.0 & $5.129 \mathrm{E} 4$ & 24010.2180 \\
Valid N (listwise) & 54 & 529237.6 & $2.5 \mathrm{E} 6$ & $1.255 \mathrm{E} 6$ & 364532.1717 \\
\hline
\end{tabular}

Sumber : Data Sekunder 2016 yang telah diolah.

Tabel 5

Kolmogrov Smirnov

\begin{tabular}{lrr}
\hline \multicolumn{2}{c}{ One-Sample Kolmogorov-Smirnov Test } & $\begin{array}{c}\text { Unstandardized } \\
\text { Residual }\end{array}$ \\
\hline $\mathrm{N}$ & Mean & 54 \\
Normal Parameters & & $2.284 \mathrm{E} 6$ \\
& Std. Deviation & $6.7408 \mathrm{E} 5$ \\
& Absolute & .114 \\
Most Extreme Differences & Positive & .114 \\
& Negative & -.101 \\
Kolmogorov-Smirnov Z & & .837 \\
Asymp. Sig. (2-tailed) & & .485 \\
\hline
\end{tabular}

a. Test distribution is Normal.

Sumber : Data Sekunder 2016 yang telah diolah 


\section{Tabel 6}

Uji Multikolinearitas

\begin{tabular}{|c|c|c|c|c|c|c|c|c|}
\hline \multicolumn{9}{|c|}{ Coefficients ${ }^{a}$} \\
\hline \multirow{2}{*}{\multicolumn{2}{|c|}{ Model }} & \multicolumn{2}{|c|}{ Unstandardized Coefficients } & \multirow{2}{*}{$\begin{array}{c}\text { Standardized } \\
\text { Coefficients } \\
\text { Beta }\end{array}$} & \multirow{2}{*}{$\mathrm{t}$} & \multirow{2}{*}{ Sig. } & \multicolumn{2}{|c|}{ Collinearity Statistics } \\
\hline & & & Std Frror & & & & Toloranco & V/F \\
\hline \multirow{5}{*}{1} & (Constant) & 143356.447 & 70841.709 & & 2.024 & .048 & & \\
\hline & PAD & 1.246 & .206 & .497 & 6.048 & .000 & .374 & 2.675 \\
\hline & DAU & .904 & .105 & .561 & 8.619 & .000 & .596 & 1.677 \\
\hline & DAK & 3.068 & 1.090 & .191 & 2.814 & .007 & .547 & 1.829 \\
\hline & $\mathrm{DBH}$ & .732 & 1.166 & .048 & .628 & .533 & .428 & 2.335 \\
\hline
\end{tabular}

a. Dependent Variabel: BELANJA

Sumber : Data Sekunder 2016 yang telah diolah

Tabel 7

\section{Uji Autokorelasi}

Model Summaryb

\begin{tabular}{cccccc}
\hline Model & $\mathrm{R}$ & R Square & Adjusted R Square & $\begin{array}{c}\text { Std. Error of the } \\
\text { Estimate }\end{array}$ & Durbin-Watson \\
1 & $.936^{\mathrm{a}}$ & .876 & .866 & 133386.6320 & 2.242 \\
\hline
\end{tabular}

a. Predictors: (Constant), DBH, DAK, DAU, PAD

b. Dependent Variabel: BELANJA

Sumber : Data Sekunder 2016 yang telah diolah

Tabel 8

\section{Koefisien Determinasi}

\begin{tabular}{ccccc}
\multicolumn{5}{c}{ Model Summary $^{\mathbf{b}}$} \\
\hline Model & $\mathrm{R}$ & R Square & Adjusted R Square & $\begin{array}{c}\text { Std. Error of the } \\
\text { Estimate }\end{array}$ \\
1 & $.936^{\mathrm{a}}$ & .876 & .866 & 133386.6320 \\
\hline
\end{tabular}

a. Predictors: (Constant), DBH, DAK, DAU, PAD

b. Dependent Variabel: BELANJA

Sumber : Data Sekunder 2016 yang telah diolah 
Tabel 9

\section{Uji Simultan}

ANOVA $^{\text {b }}$

\begin{tabular}{lrrrrr}
\hline Model & Sum of Squares & df & Mean Square & F & Sig. \\
\hline \multicolumn{1}{c}{ Regression } & $6.171 \mathrm{E} 12$ & 4 & $1.543 \mathrm{E} 12$ & 86.711 & $.000^{\mathrm{a}}$ \\
1 Residual & $8.718 \mathrm{E} 11$ & 49 & $1.779 \mathrm{E} 10$ & \\
Total & $7.043 \mathrm{E} 12$ & 53 & & \\
\hline
\end{tabular}

a. Predictors: (Constant), DBH, DAK, DAU, PAD

b. Dependent Variabel : Belanja

Sumber : Data Sekunder 2016 yang telah diolah.

\section{Tabel 10}

Uji t

Coefficients $^{\mathrm{a}}$

\begin{tabular}{|c|c|c|c|c|c|c|c|c|}
\hline \multirow{2}{*}{\multicolumn{2}{|c|}{ Model }} & \multicolumn{2}{|c|}{ Unstandardized Coefficients } & \multirow{2}{*}{$\begin{array}{c}\text { Standardized Coefficients } \\
\text { Beta }\end{array}$} & \multirow{2}{*}{$\mathrm{t}$} & \multirow{2}{*}{ Sig. } & \multicolumn{2}{|c|}{ Collinearity Statistics } \\
\hline & & B & Std. Error & & & & Tolerance & VIF \\
\hline \multirow{5}{*}{1} & (Constant) & 143356.447 & 70841.709 & & 2.024 & .048 & & \\
\hline & PAD & 1.246 & .206 & .497 & 6.048 & .000 & .374 & 2.675 \\
\hline & DAU & .904 & .105 & .561 & 8.619 & .000 & .596 & 1.677 \\
\hline & DAK & 3.068 & 1.090 & .191 & 2.814 & .007 & .547 & 1.829 \\
\hline & $\mathrm{DBH}$ & .732 & 1.166 & .048 & .628 & .533 & .428 & 2.335 \\
\hline
\end{tabular}

Sumber : Data Sekunder 2016 yang telah diolah 
Gambar 1.

Alokasi Dana Perimbangan (DAU, DAK, DBH) dan Pendapatan Asli Daerah (PAD) untuk Kemaslahatan Ummat.

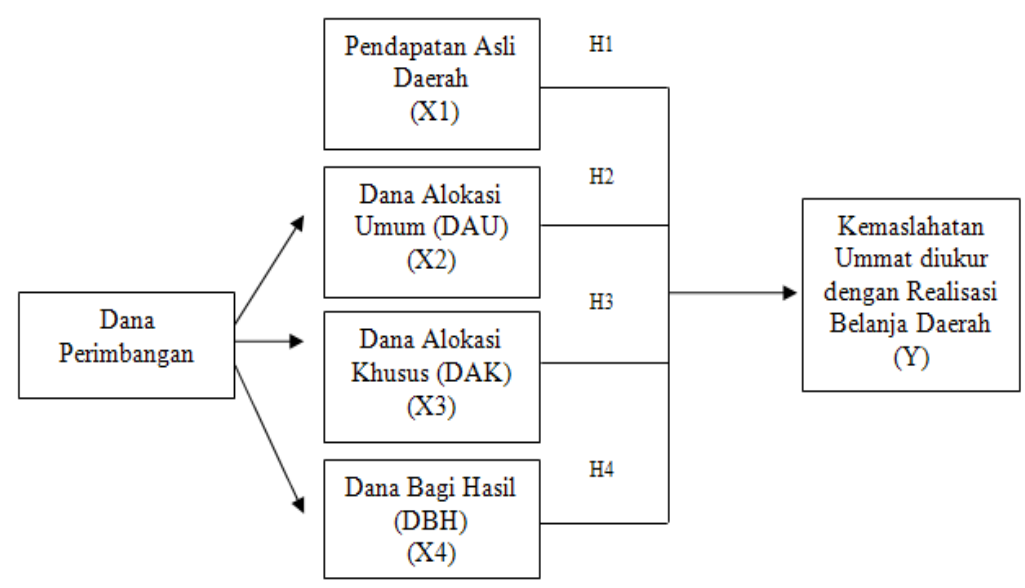

Gambar 2

Uji Normalitas

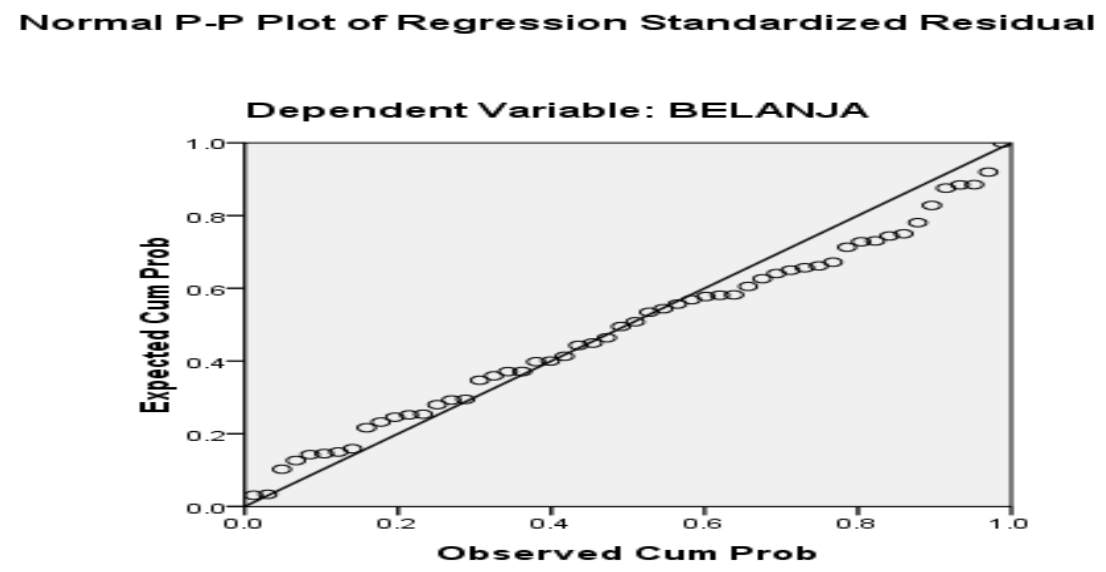

Sumber : Data Sekunder 2012 - 2013 yang telah diolah 


\section{Gambar 3}

\section{Scatterplot}

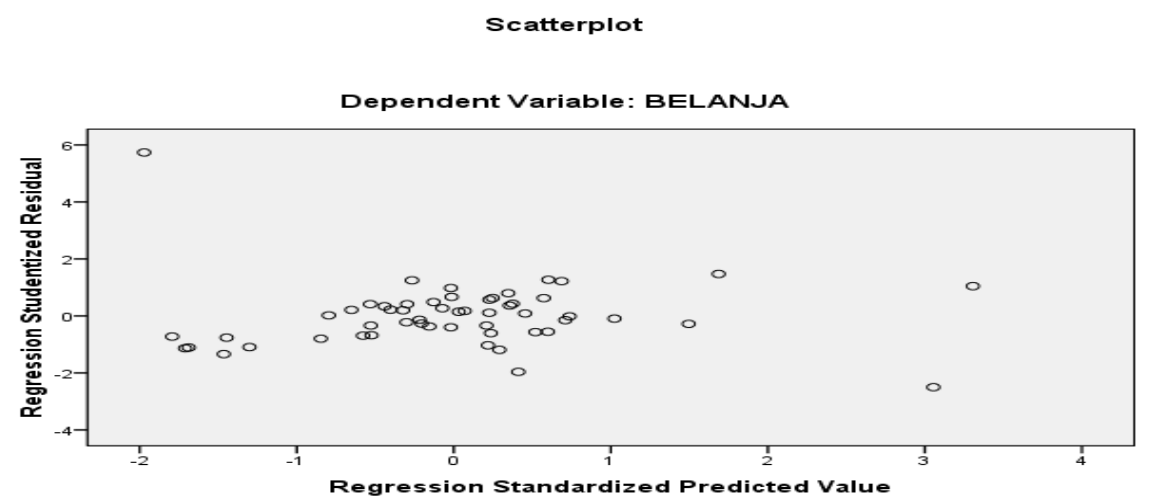

Sumber : Data Sekunder 2012 - 2013 yang telah diolah 